\title{
Oxygen isotope study of the Ibaragi granitic complex, Osaka, southwest Japan
}

\author{
YUKihiro Matsuhisa ${ }^{1}$, Yoshiaki TaINOSHO ${ }^{2}$ \\ and Osamu Matsubaya ${ }^{3}$
}

Geological Survey of Japan, 8 Kawada-cho, Shinjuku-ku, Tokyo, 162 Japan $^{1}$, Faculty of Education, Kobe University, 3-11 Tsurukabuto, Nada-ku, Kobe, $657 \mathrm{Japan}^{2}$, and Institute for Thermal Spring Research, Okayama University, Misasa-cho, Tottori-ken, $68202 \mathrm{Japan}^{3}$

\section{(Received October 2, 1973)}

\begin{abstract}
O} /{ }^{16} \mathrm{O}$ ratios were analyzed for 14 granitic rocks and their constituent minerals of the Ibaragi granitic complex near Osaka which is composed of the Nose pluton and the Myoken pluton. The whole-rock $\delta^{18} \mathrm{O}$ values of the Nose pluton are in the range from +8.1 to $+9.7 \%$ relative to SMOW. The data for the coexisting minerals suggest that an oxygen isotope equilibrium has been attained among the minerals. The $\delta^{18} \mathrm{O}$ values of the Myoken pluton are remarkably lower than those of the Nose pluton. This indicates that the magmas of the two plutons are different in their origins and/or differentiation processes. In the Nose pluton, the ${ }^{18} \mathrm{O}$-enrichment of about $1.5 \%$ is recognized in the differentiation sequence from quartz diorite to adamellite. This isotope variation can be explained as the results of equilibrium fractionation in a crystallizing magma. The $\delta^{18} \mathrm{O}$ value of the initial magma of the Nose pluton is estimated to be around $+7.5 \%$. Somewhat ${ }^{18} \mathrm{O}$-enriched materials such as metamorphic basic rocks, rather than the fresh upper mantle materials, are likely to be the source of the ${ }^{18} \mathrm{O}$-rich dioritic magma.

In the Ibaragi granitic complex, no appreciable change in oxygen isotopes is observed in the contact zone as compared to the values of main intrusive body, possibly because the country rocks have isotope ratios similar to those of the granitic rocks. An exception is found in the marginal zone of the Myoken pluton and the dike rocks, where K-feldspar may have exchanged its oxygen with the circulating $10 \mathrm{w}-{ }^{18} \mathrm{O}$ meteoric ground water.
\end{abstract}

\section{INTRODUCTION}

Granitic rocks are generally enriched in the heavy oxygen isotope, ${ }^{18} \mathrm{O}$, relative to other types of igneous rocks (TAYLOR, 1968; MATSUHISA et al., 1972). TAYLOR (1968) suggested that the ${ }^{18} \mathrm{O}$-enrichment in granitic rocks may have been caused by (1) large isotope fractionation between crystals and melt in granitic magma under lower temperature and higher $P_{\mathrm{H}_{2} \mathrm{O}}$ than in volcanic magma, or (2) magma formation by deep-seated fractional melting of ${ }^{18} \mathrm{O}$-rich metasedimentary rocks. In the previous 
study on the Cretaceous granitic rocks in Japan (MATSUHISA et al., 1972), we showed that the granitic rocks in regionally metamorphosed zones have ${ }^{18} \mathrm{O} /{ }^{16} \mathrm{O}$ ratios higher than those in non-metamorphic zones, implying that the former underwent oxygen isotope exchange with ${ }^{18} \mathrm{O}$-rich metasedimentary rocks. It was suggested that the granitic magmas prior to metasomatism had a uniform ${ }^{18} \mathrm{O} /{ }^{16} \mathrm{O}$ ratio, +8 to $+9 \%$ relative to SMOW. This is 2 to $3 \%$ higher than the values estimated for the primary basaltic magmas.

In the present study we intend to make clear the initial ${ }^{18} \mathrm{O} /{ }^{16} \mathrm{O}$ ratio of a granitic magma, as well as the magnitude of isotope fractionation during its differentiation.

The Ibaragi granitic complex in Osaka, southwest Japan, has a rock suite from quartz diorite to adamellite. These rocks are considered to have been produced by a single differentiation process of a dioritic parental magma (TAINOSHO, 1971). If the majority of granitic rocks have been produced by magmatic processes, this complex may give us some useful information on the ${ }^{18} \mathrm{O} /{ }^{16} \mathrm{O}$ ratios of granitic magma. The complex has been investigated in detail from various geochemical and geophysical points of view which include SHIbATA (1971) for K-Ar dating, IsHIzaka (1971) for Rb-Sr isotopes, NABETANi et al. (1972) for gravimetry and MASUDA et al. (1972) for rare-earth elements.

\section{Geological Settings}

The Ibaragi granitic complex is one of a series of the late Cretaceous granitic intrusions widely distributed in the Japanese Islands and the adjacent area. The geology and petrology of the complex were studied in detail by TAINOSHO (1971). Generalized geologic map of the complex is shown in Fig. 1. The complex is composed of two major plutons; the Nosé pluton and the Myoken pluton emplaced into Paleozoic formations of the Tanba zone in southwest Japan. Rb-Sr ages of the complex are $96 \mathrm{~m} . \mathrm{y}$ for the Nosé pluton and 76 to $78 \mathrm{~m} . \mathrm{y}$ for the Myoken pluton (IsHIzAKA, 1971), while K-Ar ages are 74 to $76 \mathrm{~m}$.y for both plutons (ShibATA, 1971).

The Nosé pluton crops out in an elliptical shape with an exposed area of about $30 \mathrm{~km}^{2}$. Roughly speaking, the pluton has a compositional zoning, that is, coarse to medium grained quartz diorite in the outermost portion, coarse grained granodiorite in the intermediate portion, and fine grained adamellite in the central portion. Modal composition of each rock type is tabulated in TAINOSHO (1971). Minerals include quartz, K-feldspar, plagioclase, biotite, hornblende and ilmenite. In quartz diorite, clino- and ortho-pyroxenes are contained up to 1 to $4 \%$. Plagioclase occurs in two modes, namely, in euhedral large crystal (phenocryst-plagioclase) and in interstitial small crystal (groundmass-plagioclase). Phenocryst-plagioclase shows compositional zoning; the core is roughly An60 throughout all the rock varieties, while the rim varies in composition from An40 to An20.

The Myoken pluton is a small stock with an exposure of about $8 \mathrm{~km}^{2}$ which is 


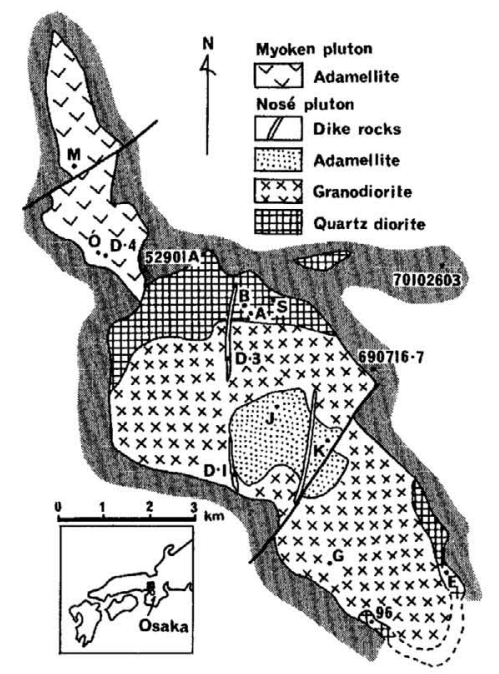

Fig.1. Generalized geologic map of the Ibaragi granitic complex, showing sample localities (after T AINOSHO, 1971). Shaded area around the complex indicates the Paleozoic formations.

intruded in the northern end of the Nose pluton. The Myoken pluton is composed of fine grained adamellite and its marginal facies. The marginal facies has porphyritic texture. The phenocryst minerals such as quartz, K-feldspar, plagioclase and hornblende are largely altered to chlorite, sericite and other clay minerals (TAINOSHO, 1973).

Two granite porphyry dikes are seen in the Nose pluton, striking N-S. K-feldspar in the phenocrysts of these dike rocks is also altered to clay minerals (TAINOsHo, 1973).

The Paleozoic formations surrounding the complex consist mainly of sandstone with some shale, volcanic rocks and chert. These rocks are weakly metamorphosed by the intrusion of granite. An aureole of biotite hornfels is observed in a belt 300 to $2,000 \mathrm{~m}$ from the contact.

\section{EXPERIMENTAL}

Rocks and minerals were decomposed with bromine pentafluoride at $500^{\circ} \mathrm{C}$. Liberated oxygen was then converted to carbon dioxide for mass spectrometric analysis. The detailed procedures were described previously (MATsuHISA et al., 1971). The isotope analysis was done in duplicate for each sample. The result is reported in conventional $\delta^{18} \mathrm{O}$ (SMOW) scale. The analytical error is within $\pm 0.2 \%$.

Samples were selected so as to cover the whole range of rock varieties of the complex. Most of them have been chemically analyzed by TAINosho (1971). Some additional samples were collected to examine the isotope exchange between the intrusive and the country rocks at their contact. The sampling localities are shown in Fig. 1. 
Quartz, K-feldspar, plagioclase and biotite in each rock sample were separated by means of hand picking, heavy liquid and a magnetic separator. The purity of separated minerals was examined under the microscope to be more than $95 \%$.

\section{REsUlts}

Tables 1 and 2 show the ${ }^{18} \mathrm{O} /{ }^{16} \mathrm{O}$ ratios of rocks and minerals from the Ibaragi granitic complex and its contact zone.

In the Nose pluton, the whole-rock samples of quartz diorite have a remarkably uniform $\delta^{18} \mathrm{O}$ value of around $+8.2 \%$. More acidic rock types in the pluton, namely, granodiorite and adamellite, are enriched in ${ }^{18} \mathrm{O}$ relative to quartz diorite by 1.0 to $1.5 \%$. In the Myoken pluton, the sample $M$ of adamellite is depleted in ${ }^{18} \mathrm{O}$ by about $3 \%$ as compared with the equivalent rock type in the Nose pluton.

$\mathrm{K}$-feldspar in the marginal facies of adamellite, the sample $O$, is abnormally depleted in ${ }^{18} \mathrm{O}$. The same trend is also found in pegmatite in the Myoken pluton

Table $1 .{ }^{18} \mathrm{O} /{ }^{16} \mathrm{O}$ ratios of rocks and minerals in the Ibaragi granitic complex

\begin{tabular}{|c|c|c|c|c|c|c|}
\hline \multirow{2}{*}{ Sample No. } & \multirow{2}{*}{ Rock type } & \multicolumn{5}{|c|}{$\delta^{18} \mathrm{O}_{\text {SMOW }}(\%)$} \\
\hline & & whole-rock & Qtz & Kf & $\mathrm{Pl}$ & $\mathrm{Bi}$ \\
\hline Nosé pluton & & & & & & - \\
\hline$S$ & $\begin{array}{l}\text { xenolith in } \\
\text { quartz diorite }\end{array}$ & +8.1 & - & - & - & - \\
\hline$A$ & quartz diorite & +8.2 & - & - & +8.9 & +5.5 \\
\hline$B$ & quartz diorite & +8.1 & +9.5 & - & +8.6 & +5.6 \\
\hline$E$ & quartz diorite & +8.2 & - & - & - & - \\
\hline$G$ & granodiorite & +9.2 & +10.6 & +9.6 & +9.0 & +5.4 \\
\hline$J$ & adamellite & +9.0 & +10.9 & +8.7 & +8.8 & +3.5 \\
\hline$K$ & adamellite & +9.7 & - & - & - & - \\
\hline \multicolumn{7}{|l|}{ Dike rocks } \\
\hline$D-1$ & granite porphyry & - & +9.2 & - & - & - \\
\hline$D-3$ & granite porphyry & - & +9.4 & +2.0 & - & - \\
\hline \multicolumn{7}{|l|}{ Myoken pluton } \\
\hline$M$ & adamellite & +6.2 & +7.4 & +6.0 & +6.1 & +2.3 \\
\hline 0 & adamellite & +5.0 & +9.1 & +4.1 & - & - \\
\hline$D-4$ & pegmatite & - & +9.1 & +1.7 & - & - \\
\hline
\end{tabular}

Abbreviations: $\mathrm{Qtz}=$ quartz, $\mathrm{Kf}=\mathrm{K}$-feldspar, $\mathrm{Pl}=$ plagioclase, $\mathrm{Bi}=$ biotite.

$(D-4)$ as well as in the dike rocks intruding into the Nosé pluton $(D-3)$.

The $\delta^{18} \mathrm{O}$ values of quartz diorite in the contact zone are +8.2 to $+8.5 \%$, being approximately the same with that of the main part of the pluton. Biotite hornfels in the metamorphic aureole has erratic ${ }^{18} \mathrm{O} /{ }^{16} \mathrm{O}$ ratios. 
Table 2. ${ }^{18} \mathrm{O} /{ }^{16} \mathrm{O}$ ratios in the contact zone of the Ibaragi granitic complex

\begin{tabular}{clccc}
\hline \multirow{2}{*}{ Sample No. } & \multirow{2}{*}{ Rock type } & \multicolumn{2}{c}{$\delta^{18} \mathrm{O}_{\text {SMOW }}(\%$ oo } & Distance from the \\
\cline { 3 - 4 } & whole-rock & biotite & contact $(\mathrm{m})$ \\
\hline $96-2$ & quartz diorite & +8.2 & +4.4 & 0.90 \\
$96-6$ & quartz diorite & +8.5 & +4.9 & 0.50 \\
$96-1$ & sandstone & +3.7 & - & 0.10 \\
$96-3$ & sandstone & +7.6 & - & 0.20 \\
$96-4$ & sandstone & +3.4 & - & 80 \\
$96-5$ & sandstone & +1.8 & & 150 \\
$52901 \mathrm{~A}$ & sandstone & +4.7 & - & 50 \\
$690716-7$ & sandstone & +12.0 & - & 100 \\
70102603 & sandstone & +8.6 & - & 2500 \\
\hline
\end{tabular}

\section{Discussion}

Oxygen isotope equilibrium among the coexisting minerals

Table 3 shows the oxygen isotope fractionations among coexisting minerals in the main rock types of this granitic complex, where $\Delta_{\mathrm{A}-\mathrm{B}}=\delta^{18} \mathrm{O}_{\mathrm{A}}-\delta^{18} \mathrm{O}_{\mathrm{B}}$. In Fig. $2 \Delta_{\text {quartz-biotite }}$ is plotted

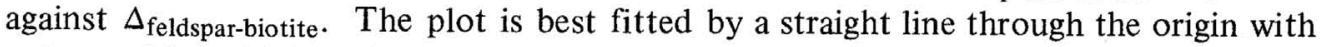
a slope of 1.4 which is almost identical with that obtained by SHIEH and TAYLOR (1969)

Table 3. Oxygen isotope fractionations and equilibrium temperatures among the coexisting minerals in the Ibaragi granitic complex

\begin{tabular}{clcccc}
\hline Sample No. & Rock type & $\Delta$ Qैtz-Kf $^{*}$ & $\Delta \mathrm{Qtz}-\mathrm{Pl}$ & $\Delta \mathrm{Qtz}-\mathrm{Bi}$ & $\left.\mathrm{T}_{\mathrm{Qtz}-\mathrm{Bi}}^{* *}{ }^{\circ} \mathrm{C}\right)$ \\
\hline Nosé pluton & & & & & \\
$B$ & quartz diorite & - & 0.9 & 3.8 & $900^{\circ}$ \\
$G$ & granodiorite & 1.0 & 1.6 & 5.2 & $640^{\circ}$ \\
$J$ & adamellite & 2.2 & 2.2 & 7.5 & $420^{\circ}$ \\
Myoken pluton & & & & & \\
$M$ & adamellite & 1.5 & 1.3 & 5.2 & $640^{\circ}$ \\
\hline
\end{tabular}

Abbreviations: $\mathrm{Qtz}=$ quartz, $\mathrm{Kf}=\mathrm{K}$-feldspar, $\mathrm{Pl}=$ plagioclase, $\mathrm{Bi}=$ biotite. $* \quad \Delta_{\mathrm{A}-\mathrm{B}}=\delta^{18} \mathrm{O}_{\mathrm{A}}-\delta^{18} \mathrm{O}_{\mathrm{B}}$.

** Isotope equilibrium temperatures were calculated on the basis of the quartzbiotite fractionations as did SHIEH and TAYLOR (1969).

for many types of igneous and metamorphic rocks. It appears that the minerals of main rock types have maintained the original isotope equilibrium at crystallization.

The equilibrium temperatures were calculated on the basis of quartz-biotite fractionation as did SHEH and TAYLOR (1969). Although the results may still be qualitative, it is clear that temperature decreases with rock type becoming more acidic (Table 3). The temperature of $900^{\circ} \mathrm{C}$ for quartz diorite seems to be too high as a crystallization temperature of granitic rocks. This may be attributed to the un- 


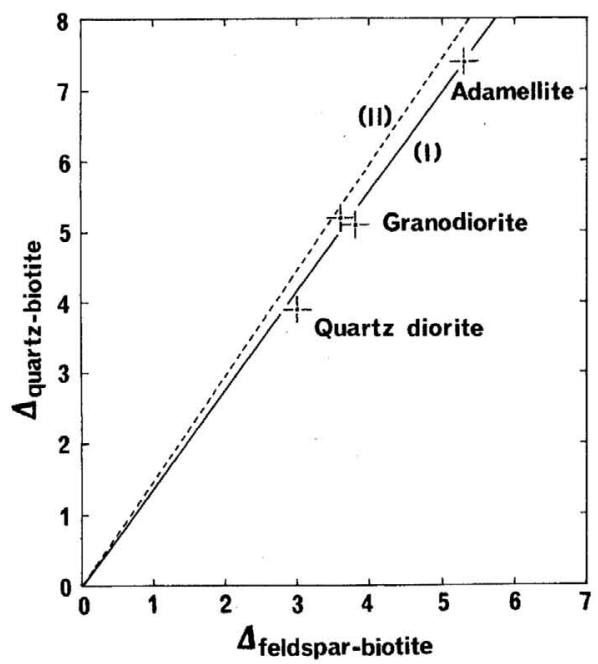

Fig.2. Plot of oxygen isotope fractionations $\Delta_{\text {quartz-biotite }}$ vs. $\Delta_{\text {feldspar- }}$ biotite for quartz-feldspar-biotite assemblages from the Ibaragi granitic complex. Line (I), slope $=1.4$, is the present work; line (II), slope $=1.5$, is after SHIEH and TAYLOR (1969) for many types of igneous and metamorphic rocks.

certainty in extrapolating the laboratory fractionation data to higher temperatures.

The $\delta^{18} \mathrm{O}$ values of hypothetical water which might have been in isotope equilibrium with the solidifying granitic rocks of the Nose pluton are calculated to be +6.5 to $+10.0 \%$. These values can be compared to $+8 \%$ estimated for a residual magmatic water of the Rokko granitic rocks in the Arima hot spring region, not far from the Ibaragi granitic complex (Matsubaya et al., 1973).

Initial ${ }^{18} \mathrm{O} /{ }^{16} \mathrm{O}$ ratio and isotope variation during differentiation of the magma In Fig. 3 the $\delta^{18} \mathrm{O}$ values of whole-rocks as well as minerals in the Nose pluton are plotted against the $\mathrm{SiO}_{2}$ weight per cent of the host rocks. The increase in $\mathrm{SiO}_{2}$ content is taken to be a tentative measure of the degree of differentiation of magma. The ${ }^{18} \mathrm{O}$ enrichment of about $1.5 \%$ is recognized in whole-rock as well as quartz during differentiation from quartz diorite to adamellite, while the $\delta^{18} \mathrm{O}$ value of plagioclase remains almost constant through the differentiation sequence. The isotope fractionation among coexisting minerals increases towards the later differentiates, reflecting the decrease in equilibrium temperature.

The whole-rock $\delta^{18} \mathrm{O}$ values, +8.1 to $+9.7 \%$, can be compared with the data for the fresh granitic rocks free from isotope exchange with ${ }^{18} \mathrm{O}$-rich metasedimentary 


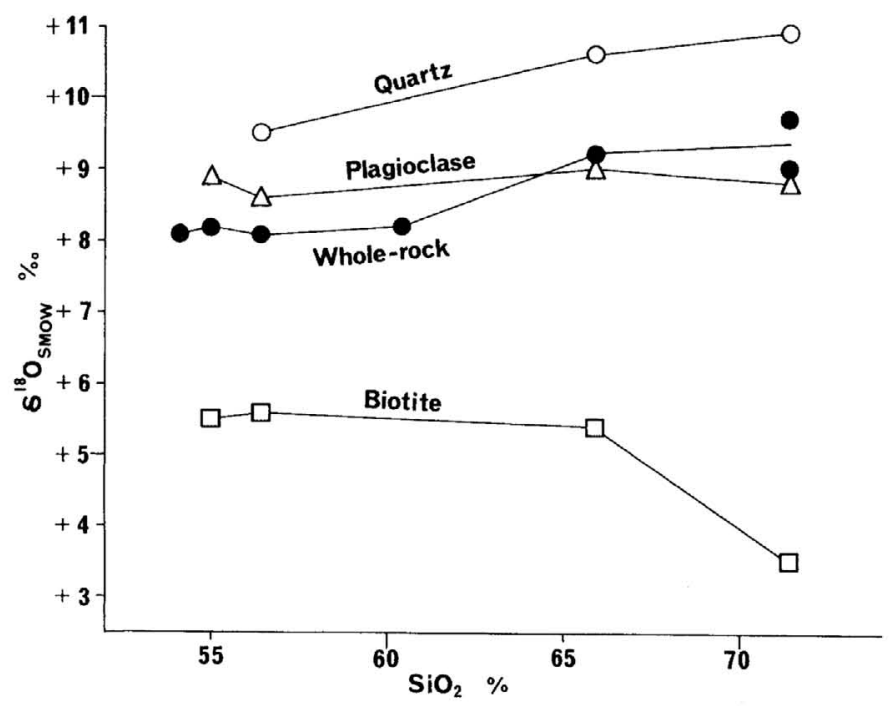

Fig.3. Variations in $\delta^{18} \mathrm{O}$ values of whole-rocks and minerals against $\mathrm{SiO}_{2}$ contents of host rocks in the Nosé pluton.

rocks (MATSuHISA et al., 1972). The study of ${ }^{87} \mathrm{Sr} /{ }^{86} \mathrm{Sr}, \mathrm{K} / \mathrm{Rb}$ and $\mathrm{K} / \mathrm{Sr}$ ratios (IsHIZAKA, 1971) also suggests that the granitic rocks of the Nosé pluton are the products of magmatic differentiation, rather than metasomatism. According to TAINOSHO (1971), the magma of the Nose pluton differentiated in a hidden reservoir and successively intruded into the shallower level. Masuda et al. (1972) showed that the rareearth distribution in this pluton could be explained by fractional crystallization of a single magma. As to oxygen isotopes, the data for coexisting minerals discussed above suggest that the minerals were crystallized in isotope equilibrium. Thus the oxygen isotope variations observed in the Nose pluton can be discussed from the view point of equilibrium fractionation in crystallization differentiation of a parental magma.

MatSUHISA et al. (1973) discussed the oxygen isotope variations in the differentiation processes of volcanic magmas by assuming that the whole-rock samples represent the liquid phases at various differentiation stages. In granitic rocks, however, wholerock samples are mixtures of primary precipitate minerals (cumulus minerals) and interprecipitate material (liquid). The comparatively large euhedral to subhedral minerals of plagioclase, hornblende and pyroxene correspond to the cumulus minerals, while the anhedral interstitial minerals represent the liquid. Plagioclase has more complicated crystallization history. The cumulus mineral of high An content crystallized in earlier stage of differentiation is captured in liquid as the core of phenocrystplagioclase in the later differentiates. The rim of phenocryst-plagioclase, whose com- 
position varies gradually from An40 to An20, is considered to be crystallized from the entrapped liquid. Plagioclase is also found among the anhedral interstitial minerals (groundmass-plagioclase), and its An content is similar to that of the rim of the euhedral zoned plagioclase. We must therefore take away cumulus minerals from the whole-rock to estimate the composition of liquid phase.

As the first approximation, let us assume that the cumulus minerals in a granitic rock are represented by pyroxene, hornblende and core of phenocryst-plagioclase. Then the $\delta^{18} \mathrm{O}$ value and $\mathrm{SiO}_{2}$ content of liquid phase may be obtained respectively by the weighted average of isotope and chemical compositions for the rest of the constituent minerals; quartz, K-feldspar, a part of plagioclase, and biotite. The calculation was done for the three main rock types of the Nose pluton; quartz diorite, granodiorite and adamellite.

Modal compositions of these rock types are presented in Table 4. The amount of cumulus plagioclase was estimated from the amount of phenocryst-plagioclase and the core/rim ratio in it, both determined under the microscope. The results are shown in Table 5. The size of crystal is about 2 by $5 \mathrm{~mm}$ to 4 by $8 \mathrm{~mm}$ for phenocryst-plagioclase, while 0.1 by $0.2 \mathrm{~mm}$ to 0.5 by $2 \mathrm{~mm}$ for groundmass-plagioclase. The amount of phenocryst-plagioclase decreases with rock type becoming more acidic, while the core/rim ratio shows little variation. The relative amount of the cumulus minerals in each rock type decreases in the sequence of differentiation; $56 \%$ in quartz diorite, $22 \%$ in granodiorite and $9 \%$ in adamellite in volume.

Table 6 shows the $\delta^{18} \mathrm{O}$ values and $\mathrm{SiO}_{2}$ contents of liquid phases (magma)

Table 4. Modal compositions of the main rock types of the Nosé pluton (after TAINOSHO, 1971)

\begin{tabular}{lccc}
\hline Mineral & Quartz diorite & Granodiorite & Adamellite \\
\hline Quartz & $15 \%$ & $25 \%$ & $32 \%$ \\
K-feldspar & 2 & 19 & 27 \\
Plagioclase & 55 & 40 & 34 \\
Biotite & 13 & 10 & 7 \\
Hornblende & 12 & 6 & - \\
Pyroxene & 3 & - & - \\
\hline
\end{tabular}

Table 5. Estimation of the amount of cumulus plagioclase

\begin{tabular}{lccccc}
\hline Rock type & $\begin{array}{c}\text { (a) } \\
\text { phenocryst- } \\
\text { plagioclase }\end{array}$ & $\begin{array}{c}\text { core part of } \\
\text { phenocryst- } \\
\text { plagioclase }\end{array}$ & $\begin{array}{c}\text { cumulus part } \\
\text { in plagioclase }\end{array}$ & $\begin{array}{c}\text { cumulus plagioclase } \\
\text { in whole-rock }\end{array}$ \\
\hline Quartz diorite & $100 \%$ & $74 \%$ & $74 \%$ & $41 \%$ \\
Granodiorite & 51 & 79 & 40 & 16 \\
Adamellite & 37 & 70 & 26 & 9 \\
\hline
\end{tabular}

* $\quad(\mathrm{c})=(\mathrm{a}) \cdot(\mathrm{b})$.

** (d) $=(\mathrm{c}) \cdot($ modal composition of plagioclase $)$. 
Table 6. Estimations of ${ }^{18} \mathrm{O} /{ }^{16} \mathrm{O}$ ratios and $\mathrm{SiO}_{2}$ contents of liquid phases for the main rock types of the Nose pluton

\begin{tabular}{lcc}
\hline \hline Rock type & $\delta^{18} \mathrm{O}_{\mathrm{SMOW}}(\%)$ & $\mathrm{SiO}_{2}(\mathrm{wt} \%)$ \\
\hline Quart diorite & +8.1 & 61 \\
Granodiorite & +9.2 & 71 \\
Adamellite & +9.1 & 74 \\
\hline
\end{tabular}

calculated for the main rock types of the Nose pluton on the basis of the model described above. In quartz diorite, the $\delta^{18} \mathrm{O}$ value of liquid phase is calculated to be $+8.1 \%$. This is similar to the whole-rock value, thus indicating little, if any, difference in the isotopic value between the cumulus and the liquid phase. The precipitates must be poorer in ${ }^{18} \mathrm{O}$ than the coexisting liquid phase to produce ${ }^{18} \mathrm{O}$-enrichment in magma during crystallization differentiation. Therefore, the present result implies that the composition of cumulus phase captured in liquid phase is ${ }^{18} \mathrm{O}$-richer and more acidic than the primarily precipitated mineral assemblage by selective sinking of mafic minerals in the magma reservoir. Whatever the true mechanism is, it seems difficult to know exactly the magnitude of isotope fractionation between the cumulus and the liquid phase at any stage of crystallization.

In Fig. 4 the variation of $\delta^{18} \mathrm{O}$ value vs. $\mathrm{SiO}_{2}$ content for liquid phases (magma) as well as for whole-rock samples of the Nose pluton are compared with those for the Quaternary volcanic rocks of the Japanese Islands (MATSUHISA et al., 1973). The plots for the liquid phases and the whole-rock samples do not much differ from each

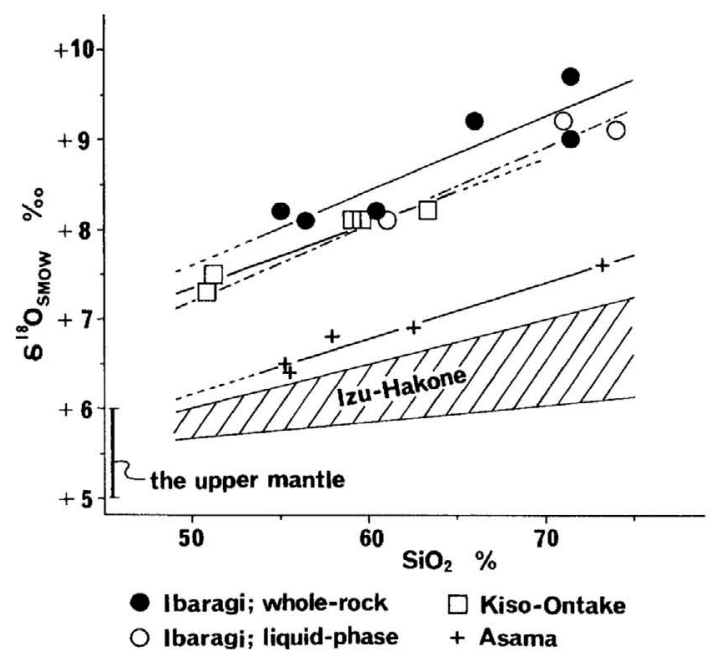

Fig.4. Oxygen isotope variation during differentiation of the-magma of the Nosé pluton, together with isotope variation trends of several volcanic rock suites obtained by MATSUHISA et al. (1973). The dash-dot represents liquid phases of the Nosé pluton. 
other, although the former gives slightly lower $\delta^{18} \mathrm{O}$ values. It is seen that the variation trend of the Nose pluton is very similar to that of the Kiso-Ontake volcanic rock suite. The $\delta^{18} \mathrm{O}$ value of the Nose pluton extrapolated to the $\mathrm{SiO}_{2}$ content of $50 \%$ is +7.2 (for liquid phase) or $+7.6 \%$ (for whole-rock) which is compared to +7.3 to $+7.5 \%$ of the least-differentiated rocks in the Kiso-Ontake volcanic rock suite. These values are over $1 \%$ heavier than the $\delta^{18} \mathrm{O}$ values of the parental magmas estimated for the Izu-Hakone and Asama volcanic rock suites (MATsuHISA et al., 1973). So called calc-alkaline rock suites seem to include multiple magma series different in their origins and differentiation processes; the group of Ibaragi and Kiso-Ontake may represent one, and the group of Asama another.

The $\delta^{18} \mathrm{O}$ values of the fresh upper mantle materials are estimated to lie in the range of +4.5 to $+6.0 \%$ (O Numa et al., 1972). Tholeiites and alkaline basalts probably produced by partial melting of the upper mantle materials have uniform $\delta^{18} \mathrm{O}$ values, +5.5 to $+6.0 \%$ (Matsuhisa et al., 1973). This implies that a magma having a $\delta^{18} \mathrm{O}$ value as high as +7.0 to $+7.5 \%$ could not be a direct product of partial melting of the upper mantle materials. One might suggest that ${ }^{18} \mathrm{O}$-rich sedimentary or metamorphic rocks were involved in magma genesis of the Nosé pluton and the KisoOntake volcanic rocks. According to the Sr-isotope study (IsHIZAKA, 1971), however, assimilation of large amounts of sediments to the magma is most unlikely for the Nosé pluton. Metamorphic basic rocks such as amphibolites and eclogites are also enriched in ${ }^{18} \mathrm{O}$ (TAylor and EPSTEIn, 1962; SchWARCZ and Clayton, 1965; TAYlor and Coleman, 1968). Such a rock may be one of the possible source of the ${ }^{18} \mathrm{O}$-rich dioritic magmas.

There has been suggestion that calc-alkaline magma in the island arc is produced by partial melting of quartz eclogite which has been transformed from the subducting abyssal basalts or by partial melting of the basalts under wet conditions (RINGWOOD and GreEn, 1966; GreEN and Ringwood, 1968). Abyssal basalts are known to be enriched in ${ }^{18} \mathrm{O}$ by submarine weathering processes (GARLICK and DYMOND, 1970; MUEHLENBACHS and Clayton, 1972a). On the other hand, submarine greenstones have $\delta^{18} \mathrm{O}$ values slightly lower than fresh basalts as the result of isotope exchange with sea water in metamorphism (Muenlenbachs and Clayton, 1972b). Therefore, importance of the submarine basic rocks as the ${ }^{18} \mathrm{O}$-rich source material is not very clear at present.

The $\delta^{18} \mathrm{O}$ value of $+6.2 \%$ of adamellite (sample $M$ ) in the Myoken pluton is unusually low (Table 1). Only four out of more than sixty granitic rocks investigated by TAYLOR (1968) have $\delta^{18} \mathrm{O}$ values lower than $+7.0 \%$. As the minerals in sample $M$ are found to be in isotope equilibrium at a temperature indicating magmatic condition (see Table 3 and Fig. 2), the whole-rock $\delta^{18} \mathrm{O}$ value must be close to the value of magma. Although further investigations are required, it appears probable that the magma of the Myoken pluton was isotopically different from that of the Nose pluton. 
Isotope exchange of the granitic rocks with the extraneous materials Oxygen isotope interactions between igneous intrusions and surrounding rocks are variable depending on the mode of emplacement and the nature of the country rocks (SHIEH and TAYlor, 1969; Turi and TAYlor, 1971a; 1971b). In the Nosé pluton $\delta^{18} \mathrm{O}$ values of quartz diorites in the contact zone, even within $1 \mathrm{~m}$ from the contact, are not deviated from the values of the main part of the intrusion (Table 2). The $\delta^{18} \mathrm{O}$ value of sandstone about $2,500 \mathrm{~m}$ from the contact is $+8.6 \%$ (70102603 in Table 2), being close to the value of the granitic rocks. Therefore, the intrusion may have been subjected to little change in oxygen isotopes even though the material transfer must have taken place in the contact zone.

The $\delta^{18} \mathrm{O}$ values of sandstones from the biotite hornfels aureole range from +1.8 to $+12.0 \%$ with no apparent correlation to the distance from the intrusive contact (Table 2). The lowering of ${ }^{18} \mathrm{O}$ content in the hornfels may partly be caused by the recrystallization of biotite and/or the isotope exchange between feldspar and $10 w^{-18} \mathrm{O}$ meteoric ground water.

In the marginal facies of adamellite $(O)$ and pegmatite $(D-4)$ in the Myoken pluton, and also in the dike rocks $(D-3)$ intruded into the Nose pluton, the isotope fractionations between quartz and K-feldspar are 5 to $7 \%$. Such a large fractionation indicates that these mineral pairs are not in isotope equilibrium at magmatic temperatures. Since the $\delta^{18} \mathrm{O}$ values of quartz in these samples are identical with those in the main rock types, the observed isotope fractionations may have been caused by secondary isotope exchange between $\mathrm{K}$-feldspar and certain ${ }^{18} \mathrm{O}$-depleted materials after the solidification of granitic magma. Textures of these rocks indicate that they were intruded into a shallow level and were altered under a hydrothermal condition after crystallization (TAINOSHO, 1971; 1973). In the marginal facies of the Myoken pluton, $\mathrm{K} / \mathrm{Rb}$ and $\mathrm{K} / \mathrm{Sr}$ ratios are distinctly deviated from the trend lines induced from the main rock types (ISHIZAKA, 1971). MASUDA et al. (1972) also found the unusual rare-earth concentrations in these rocks, and suggested that lighter rare-earth elements migrated from the granite to the country rocks. The migration of elements could have been encouraged by the presence of hydrothermal water. Feldspar may have selectively exchanged its oxygen with the circulating $10{ }^{18}-{ }^{18}$ meteoric ground water under hydrothermal conditions, as has been discussed in epizonal igneous intrusions by TAYLOR (1971) and TAYLOR and FORESTER (1971).

\section{CONCLuSIONS}

(1) The two plutons constituting the Ibaragi granitic complex; the Nose pluton and the Myoken pluton, are different in oxygen isotopes. This may indicate that the magmas of the two plutons are different in their origins and differentiation processes.

(2) The ${ }^{18} \mathrm{O}$-enrichment found in the differentiation sequence of the Nose pluton 
can be explained by equilibrium fractionations during crystallization differentiation of a single parental magma. Equilibrium temperature decreases with host rock composition becoming more acidic.

(3) The initial $\delta^{18} \mathrm{O}$ value of magma of the Nose pluton is estimated to be at least above $+7.2 \%$ relative to SMOW. This magma might have been produced by melting of somewhat ${ }^{18} \mathrm{O}$-enriched source rather than the fresh upper mantle materials. Metamorphic basic rocks may be one of the possible source.

(4) Oxygen isotope exchange with the country rocks may not have taken place in the Ibaragi granitic complex. However, in some rocks such as the marginal facies of the Myoken pluton and the dike rocks, K-feldspar seems to have exchanged its oxygen with low- ${ }^{18} \mathrm{O}$ meteoric ground water after crystallization.

\section{ACKNOWLEDGMENTS}

We are indebted to Professors Hrtoshi SAKaI and TaKashi MATSumoto of the Institute for Thermal Spring Research, Okayama University for their valuable advices and helpful criticisms on the present study. We are grateful to Dr. AKIRA SASAKI of Geological Survey of Japan for his kindly reviewing the manuscript. Isotope measurements in the present study were made in the Institute for Thermal Spring Research, Okayama University. Thanks are also due to the skilful assistance by Misses SATOMI MASHima and TAzUe Uemura of the Institute.

\section{REFERENCES}

GaRlick, G. D., and Dymond, J. R. (1970) Oxygen isotope exchange between volcanic materials and ocean water. Geol. Soc. Am. Bull. 81, 2137-2142.

GREEN, T. H. and Ringwood, A. E. (1968) Genesis of the calc-alkaline igneous rock suite. Contr. Mineral. and Petrol. 18, 105-162.

ISHIZAKA, K. (1971) A Rb-Sr isotopic study of the Ibaragi granitic complex, Osaka, Japan. J. Geol. Soc. Japan 77, 731-740.

Masuda, Y., YAGI, S., Nishimura, S., and ASAYAma, T. (1972) Rare-earth distributions in the Ibaragi granitic complex, Osaka Prefecture, Japan. ibid. 78, 521-530.

Matsubaya, O., Sakai, H., Kusachi, I., and Satake, H. (1973) Hydrogen and oxygen isotopic ratios and major element chemistry of Japanese thermal water systems. Geochem. J. 7, 123-151.

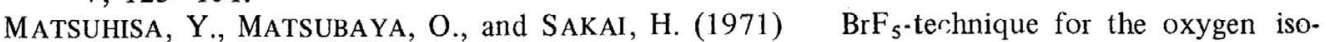
topic analysis of silicates and water. Mass Spectroscopy 19, 124-133 (in Japanese with English abstract).

Matsuhisa, Y., Honma, H., Matsubaya, O., and Sakai, H. (1972) Oxygen isotopic study of the Cretaceous granitic rocks in Japan. Contr. Mineral. and Petrol. 37, 65-74.

Matsuhisa, Y., MATSUbAYA, O., and SAKAI, H. (1973) Oxygen isotope variations in magmatic differentiation processes of the volcanic rocks in Japan. ibid. 39, 277-288.

Muehlenbachs, K., and Clayton, R. N. (1972a) Oxygen isotope studies of fresh and weathered submarine basalts. Canad. J. Earth Sci. 9, 172-184.

MUehlenBACHS, K., and Clayton, R. N. (1972b) Oxygen isotope geochemistry of submarine greenstones. ibid. 9, 471-478. 
NABetani, S., SuzUKI, M., Nozawa, T., and TAINosho, Y. (1972) Gravimetric investigation of the Ibaragi granitic complex. J. Geodetic Soc. Japan 18, 78-88 (in Japanese with English abstract).

Onuma, N., Clayton, R. N., and Mayeda, T. K. (1972) Oxygen isotope cosmothermometer. Geochim. Cosmochim. Acta 36, 169-188.

RiNGwOOD, A. E., and GREEN, D. H. (1966) An experimental investigation of the gabbro-eclogite transformation and some geophysical implications. Tectonophysics 3, 383-427.

SCHWARCZ, H. P., and CLAYTON, R. N. (1965) Oxygen isotope studies of amphibolites. Canad. J. Earth Sci. 2, 72-84.

Shibata, K. (1971) K-Ar age of the Ibaragi granitic complex. Chikyu-Kagaku (Earth Science) 25, 268-269 (in Japanese).

SHIEH, Y. N., and TAYLOR, JR., H. P. (1969) Oxygen and hydrogen isotope studies of contact metamorphism in the Santa Rosa Range, Nevada and other areas. Contr. Mineral. and Petrol. 20, 306-356.

TAINOSHO, Y. (1971) Petrology of the Ibaragi granitic complex in the northern part of Osaka Prefecture, Japan. J. Geol. Soc. Japan 77, 57-70 (in Japanese with English abstract).

TAINOSHO, Y. (1973) Granites of the Myoken pluton in the northern part of Osaka Prefecture, Japan. Bull. Facul. Education, Kobe Univ. 48, 99-121 (in Japanese with English abstract).

TAYLOR, JR., H. P. (1968) The oxygen isotope geochemistry of igneous rocks. Contr. Mineral. and Petrol. 19, 1-71.

TAYLOR, JR., H. P. (1971) Oxygen isotope evidence for large-scale interaction between meteoric ground waters and Tertiary granodiorite intrusions, Western Cascade Range, Oregon. J. Geophys. Res. 76, 7855-7874.

TAYLOR, JR., H. P., and EPSTEIN, S. (1962) Relationship between ${ }^{18} \mathrm{O} /{ }^{16} \mathrm{O}$ ratios in coexisting minerals of igneous and metamorphic rocks. Geol. Soc. Am. Bull. 73, 461-480.

TAYlOR, JR., H. P., and COLEMAN, R. G. (1968) ${ }^{18} \mathrm{O} /{ }^{16} \mathrm{O}$ ratios of coexisting minerals in glaucophane-bearing metamorphic rocks. ibid. 79, 1727-1756.

TAYLOR, JR., H. P., and FORESTER, R. W. (1971) Low. ${ }^{18}$ O igneous rocks from the intrusive complexes of Skye, Mull, and Ardnamurchan, Western Scotland. J. Petrol. 12, 465-497.

TURI, B., and TAYLOR, JR., H. P. (1971a) An oxygen and hydrogen isotope study of a granodiorite pluton from the Southern California batholith. Geochim. Cosmochim. Acta 35, 383406.

TURI, B., and TAYLOR, JR., H. P. (1971b) ${ }^{18} \mathrm{O} /{ }^{16} \mathrm{O}$ ratios of the Johnny Lyon granodiorite and Texas Canyon quartz monzonite plutons, Arizona, and their contact aureoles. Contr. Mineral. and Petrol. 32, 138-146. 